\title{
Research on Ecological Water Rights Violations and Protection Systems in the Lower Reaches of the Yellow River
}

\author{
Xiangwei Qiu, Jilian Hu* \\ School of Economics and Management, Shandong Agricultural University, Taian, China \\ Email: qxw0609@outlook.com, *jlhu@sdau.edu.cn
}

How to cite this paper: Qiu, X.W. and Hu, J.L. (2018) Research on Ecological Water Rights Violations and Protection Systems in the Lower Reaches of the Yellow River. Journal of Service Science and Management, 11, 182-202.

https://doi.org/10.4236/jssm.2018.112014

Received: March 17, 2018

Accepted: April 17, 2018

Published: April 20, 2018

Copyright $\odot 2018$ by authors and Scientific Research Publishing Inc. This work is licensed under the Creative Commons Attribution International License (CC BY 4.0).

http://creativecommons.org/licenses/by/4.0/

(c) (i) Open Access

\begin{abstract}
Overcoming the cut-off problem doesn't mean the realization of Yellow River ecological water rights because the social water is still occupying the ecological water in a number of ways. This paper analyzes the lower reaches of the Yellow River's ecological water rights crisis and illustrates that the property rights of the ecological water rights are low. The systematic root of low property rights of the ecological water rights lies in the stagnant construction of water rights systems and insufficient supply of protection systems, which are presented by unclearly defined subjects and objects of the ecological water rights, the ambiguous water rights ranking system and the imperfect water rights allocation mechanism. In this paper, the authors put forward the optimization path of safeguarding the ecological water rights, including defining the subject and object of the ecological water rights of the Yellow River, clearing rights responsibility and benefits; refining the water rights ranking system and having the ranks of ecological water rights advanced; strengthening the effective supply of ecological water by utilizing the water rights market; upgrading the management system of ecological water rights and boosting the labor division and collaboration among water management organs.
\end{abstract}

\section{Keywords}

The Lower Reaches of the Yellow River, Ecological Water Rights, Protection System

\section{Introduction}

Prior to the 1970s, the economic development level of our country remained a

${ }^{*}$ Corresponding author. 
low level, with little demand for economic social water use, due to which the supply of ecological water by the Yellow River was abundant enough, and such problem as ecological water being occupied by social water barely existed. With the increasing expansion of farmland along the banks of the Yellow River, as well as the increase of industrialization and urbanization, demands for agricultural irrigation water, industrial production water and domestic water used by urban-and-rural residents all skyrocketed, which resulted in aggravation of water resource scarcity and gradual or even complete occupation of ecological water of the Yellow River. From the 1970's to the 1990's, the cut-off crisis occurred to the lower reaches of the Yellow River in successive years, severely threatening the health of the Yellow River. The sustainable supply of ecological water is a guarantee of healthy development to rivers as well as a precondition for the sustainable economic and social development of the Yellow River basin. The State Council initiated a package of water allocation plans and dispatching management methods with the "1987 Water Allocation Plan" as representative, in order to guarantee the ecological water quantity and solve the cut-off problem of the Yellow River through reserving ecological water quantity, which has to some extent drawn the line between the water "consumption" by the society and the water "reservation" by the ecology. The essence of this array of policies and actions is that they have specified that the river, as one of the main water users, enjoys the rights of using river water as a resource as well, which are namely the ecological water rights. As bound upon by this system, the Yellow River ultimately ends its 27 years of cut-off history, and the basic ecological water rights of the Yellow River have been realized.

However, overcoming the cut-off problem doesn't mean that the ecological water rights of the Yellow River (the lower reaches in particular) have been practically guaranteed. On the one hand, the Yellow River's cut-off appeasement is actually superficial rather than functional, and the actual ecological water consumption quantity is still lower than the ideal ecological water demand due to occupation and violation of social water rights; on the other hand, the economic and social development of the provinces along the Yellow River is followed by a rapid increase in the amount of waste water discharged into the Yellow River, which results in the fact that the water quality of numerous reaches is not up to that of ecological water and thus cannot meet the water demands of aquatic organisms, generating a negative impact on the full play of ecological functions of the river channel. The "scarcity of water resources" has become the new crisis faced by the ecological water rights of the Yellow River.

The systemic root of the violation of ecological water rights lies in the stagnant construction of the water rights systems and the insufficient supply of protection systems. This paper employs the conceptual tool of "property rights quality" and sets the ecological water rights in the lower reaches of the Yellow River as the study object, exploring and analyzing the systemic root of the violation of the Yellow River ecological water rights as well as its optimization path 
with the start of property characteristics of ecological water rights.

\section{Current Status of Ecological Water Rights Violations in the Lower Reaches of the Yellow River and Its Influence}

The Yellow River basin features abundant habitat types, and the biotic communities along the river are full of characteristics, wherein the estuary delta area, located in the lower reaches of the Yellow River, is the most extensive and complete original wetland ecosystem in the warm temperature zone of our country, with relatively more fish reserves, with migratory fish like mullet and coiliaectenes being the main species. As a result of the distinctive geographical environment, the ecological vulnerability of the lower reaches of the Yellow River manifests itself obviously. As a "corridor" connecting ecological wetland units from the rivers source, upper, middle \& lower reaches to the estuaries, the Yellow River ecological water with its quality and quantity guaranteed is the prerequisite for the realization of ecological functions of the Yellow River as well as the key foundation for the stability of eco-environment systems in the lower reaches, and the preservation of existence and multiplication of aquatic organisms in the river. Owing to the increase of economic social water use and the over-use by provinces in the upper reaches, neither quality nor quantity of the ecological water in the lower reaches of the Yellow River is qualified. The Yellow River's ecological functions are damaged, and the eco-environment problems in the lower reaches are serious.

\subsection{Current Status of Ecological Water Rights Violation in the Lower Reaches of the Yellow River}

\subsubsection{Insufficient Quantity of Ecological Water}

Water serves as one of the very fundamental production factors for existence and development of human society, and rapid social and the economic booming of the Yellow River basin means the corresponding input of water quantity. It is recorded that the gross quantity of water intake from the Yellow River soared from 12.2 billion $\mathrm{m}^{3}$ to 53.463 billion $\mathrm{m}^{3}$ from 1949 to 2015, an increase of almost 3.4 times. ${ }^{1}$ The exploitation and utilization ratio of the Yellow River water resource was generally above $70 \%$, and even reached $92 \%$ at the start of this century, far beyond $40 \%$, the national-standard "red line" of ecological security (Qing Su, 2006) [1]. Therefore, the economic development of the Yellow River basin is at the price of the violation of the ecological water. Agriculture is a large consuming party within the current water-use structure of the Yellow River, and the agricultural irrigation water can be as much as $70 \%$ of the gross quantity of the water intake. The Yellow River basin, as one of the grain production areas of the nation, has now boasted an irrigation area of 10 times the one in the wake of New China's founding. Besides, the water consumption for industrial production and urban-and-rural resident usage increases dramatically with the increase of industrialization and urbanization.

${ }^{1}$ Source: The Yellow River Water Resources Bulletin (1998-2005). 
A typical manifestation of the over-occupation of the Yellow River's ecological water is the cut-off phenomenon of the lower reaches. The cut-off problem occurred to Lijin Station in the lower reaches of the Yellow River for the very first time in 1972, which then happened annually until 1987, with the cut-off date continuously becoming earlier, the scope broader and the frequency more intensive. From 1987 to 1996, the cut-off occurred 57 times, and lasted 682 days. In 1994, the cut-off extended to Chenqiao close to Kaifeng City of Henan Province, with a length of $683 \mathrm{~km}$ that accounts for $87 \%$ of the lower reaches. In 1997, the cut-off lasted 226 days, which was the longest in history. Even though the issuance of a package of water management measures with the representative "1987 Water Allocation Plan" preliminarily helped solve and control the cut-off problem of the Yellow River, its eco-environment functions were still restricted by the shortage of the water consumption quantity. It was estimated that the ecological water deficit of the Yellow River around the year 2000 was still 53\% $75 \%$ [2].

\subsubsection{Unguaranteed Quality of Ecological Water}

In recent years, the economic development was coupled with the continuous increase of waste water discharged into the Yellow River. In 2015, the gross quantity of waste water discharged into the Yellow River was approximately 4.401 billion tons, over two times of that of the 1980's. The water quality in parts of the reaches gradually went beyond the bearing capacity of the river's ecosystems. It was calculated that the cross section, with at least IV-class water quality, accounted for $66 \%$ of the 44 nationally controlled surface-water monitoring sections in the main stream of the Yellow River ${ }^{2}$. The length of the Yellow River with poor V-class water quality always accounted for more than $20 \%$ of the evaluated gross river length in the last 10 years, which even reached 26.2\% in 2015, more than one quarter of the gross river length. In addition, due to the water flowing characteristic, pollutants throughout the way were ultimately piled in the lower reaches, and the water quality of the Shandong cross section at the end of lower reaches usually failed III-class standard requirements for water environment function area, regarded as the area with the most serious pollution. Xiqin Wang et al. (2008) even evaluated the quality of the Yellow River's ecological water by adopting the ratio between waste water discharge volume and river runoff volume, with the result of a very-poor grade. In the mean time, it was mentioned that the discharge of waste water into the river channel supplemented the quantity of ecological water while downgrading its quality, which is the reason that the Yellow River's ecological water is attributed as the "scarcity of water resources" [3].

\subsection{Direct Influence of Ecological Water Rights Violation in the Lower Reaches of the Yellow River}

The Yellow River ranks the top in the world for its sediment concentration, with ${ }^{2}$ Source: The Yellow River Water Resources Bulletin (1998-2005). 
annual average sediment runoff as high as 1.6 billion tones. Due to the over-use of water, the flow allocated by the lower reaches of the Yellow River plummeted from $7000 \mathrm{~m}^{3} / \mathrm{s}$ in the 1970 's to less than $2000 \mathrm{~m}^{3} / \mathrm{s}$, which then recovered to $2900 \mathrm{~m}^{3} / \mathrm{s}$ after the third water-and-sediment tests [1]. As the water flow of the lower reaches decreased, the Yellow River's channel functions, like sediment transportation for flood prevention, were severely influenced, resulting in the fact that a great amount of sediment settled in the main river channel, which constantly aggravated the state of "secondary suspended river" of the river channel in the lower reaches, and was prone to cause dike breach and inundation, threatening the lives and property safety of residents living along the river. The deposited bottom-land and riverbed of the channel were bared, which led to frequent sand storm under the monsoon climate. The animals and plants contained in the river are able to disintegrate pollutants, but reduced runoff volume resulted in the lowering of the animal and plant content, and the river channel's functions like dilution, purification and pollution-carrying capacity were therefore reduced.

\subsubsection{Damaged Habitat Environment of Aquatic Organism and Reduced Biodiversity in the River Channel}

The increase of waste water discharge kept deteriorating the river's water quality and threatened the existence and multiplication of aquatic organisms within the basin, causing a reduction in species diversity and the loss of biotic population and genetic diversity in the river. The pollutant concentration in the main rivers exceeded the water quality standard for the fishing industry and even reached, or surpassed, the lethal concentration for fish in the middle and lower reaches of certain tributaries, where few fish still existed. The cut-off problem has broken the water-environment balance of the Yellow River delta wetland, severely threatening the existence and the multiplication of thousands of aquatic organisms, wild plants and over 180 kinds of birds in the wetland reserve, and leading to the decrease of the biotic population quantity, making the structure even simpler. Japanese eel and Acipenserdabryanus, a migratory fish in the Yellow River delta area, scarcely exist now, and the distribution quantity of important economic species like pagrosomus major and trichiurushaumela in Laizhou Bay has dropped sharply.

\subsubsection{Downgraded Lakes and Wetlands within the Basin Shrink, and the Terrestrial Ecosystem}

Lakes and wetlands feature functions like flood diversion and storage, climate regulation, water quality purification and species diversity protection, etc. Rivers are the feeding water source of lakes and wetlands. The shortage of ecological water in the Yellow River channel has caused the violation and recession of lakes and wetlands alongside the Yellow River. In accordance with the 2nd Survey of Wetland Resources of Shandong Province from 2011 to 2013, compared with the results of the 1st survey (1996-2000), the total wetland area in Shandong Province decreased by $10.93 \%$, with natural wetlands and important wetlands being 
decreased obviously, and the natural wetland area of the whole province reduced by 637,200 hectares (from $1,681,500$ to $1,044,300$ hectares), with a reduction rate of $37.89 \%^{2}$. With less water input, the Yellow River delta suffered severe violation and recession, land salinization of the estuary area was continuously aggravated, and the water environment of the wetland lost its balance. Land salinization and desertification of the estuary area degraded the wetlands ecosystem. The land vegetation of the Yellow River delta therefore became tremendously fragile and apt to be superseded. The vegetation is mainly grassland, and currently there are 2.18 million $\mathrm{km}^{2}$ of grassland of diverse kinds, wherein, 1.85 million $\mathrm{km}^{2}$ of grassland is natural grassland. The cut-off problem not only caused land salinization but also degraded the grassland into halophytic vegetation. On the other hand, it generated negative impact on the growth of artificial grassland as well.

\subsubsection{Damaged off Shore Sea Ecosystem and Declined Biodiversity}

The Yellow River's annual water volume poured into sea was almost 30 billion $\mathrm{m}^{3}$ before 1980s, which now decreased by $47 \%$ [4]. The cut-off resulted in Bohai Sea's loss of important resource of fish feed, influencing on the multiplication of marine organism and interrupting the migration of a dozen of fish species. Meanwhile, less water pouring and higher pollutant concentration in the sea caused deterioration phenomena of eco-environment like water eutrophication and imbalance of nutritive salt, which further led to different levels of destruction of ecosystem in the offshore area of the Yellow River (not least the Yellow River estuary and Laizhou Bay), biodiversity decrease and ecosystem-servicing function degradation.

\section{Property Rights Causes for Ecological Water Rights Violation in the Lower Reaches of the Yellow River}

Essentially speaking, ecological water violation is an issue of a water rights conflict between the ecological water rights and social water rights in the property-rights common to the Yellow River. The system, as one of key endogenous variables of resource allocation efficiency, restrains human opportunistic behavior to try to have the resource utilization conflicts avoided and resolved [5]. Incomplete water rights systems play a role in the systemic root of the vulnerability for the current ecological water rights.

\subsection{Influence of Resource Allocation on Property Rights Quality and System Arrangement}

The property rights system features functions like uncertainty reduction, externality internalization, motivation, refraining and resource allocation, etc. The exertion of the property rights functions are based on the property rights' effective enforcement, the efficiency of which hinges on the quality of the "property

${ }^{3}$ Source: the second wetland resources survey press conference of Shandong province 2014-05-21 (http://news.iqilu.com/shandong/yuanchuang/2014/0521/1998015.shtml) 
rights quality". The higher the property rights quality is, the higher the property rights' performance efficiency grows, and the more sufficiently the property rights functions play correspondingly. The property rights quality may be reflected by the property rights element characteristics, which includes exclusiveness, transferability, decomposability, enforceability and limitation, wherein, the exclusiveness serves as the main element of vector. The characteristic elements of property rights correlate with each other, and enhancement of any one element (not least the exclusiveness) will lead to corresponding reinforcement of other elements, which then have the quality or intensity of the property rights elevated as a whole.

The intensity of element characteristics of certain property rights is determined by both the resource characteristics and the property rights system. The property rights system refers to the serial rules about division, defining, protection and enforcement of the property rights, with social compacts and legal systems as the main kinds. Absence of property rights systems or irrationality of property rights arrangements will lower property rights quality or weaken property rights intensity. When property rights conflicts occur to the common or neighborhood of property rights, those property rights with lower quality are likely to be violated. This requires property rights system changes to enhance element characteristics like exclusiveness and limitation (namely changing property rights structure) so as to improve property rights quality, achieving the effect of exerting property rights functions and solving property rights conflicts.

\subsection{Evaluation on the Property Rights Quality of the Water Rights of the Yellow River}

\subsubsection{Strong Externality}

The river's functions are mainly manifested by the aspects of resource functions and ecological \& environmental functions. The meeting of ecological water will give full play to the ecological \& environmental functions of the rivers resources, and the ecological benefits generated feature public interest, with remarkably positive externality. Therefore, the ecological water rights feature strong externality.

1) Common externality of ecological water rights. The property rights common means the cross section among function scopes and interaction spaces of different property rights. The degree of the river's ecological water satisfaction not only determines development of the river's ecosystem but also forms externality, for exertion on the river's other functions. For instance, when the ecological water is at a sufficient amount, the river may fully exert its function of independently cleaning the received contaminants and help improve the quality of social water, in which case the ecological water rights form positive externality to the social water rights. In addition, the ecosystem is a gigantic ecosphere, and the stability of the river's ecosystem plays an important role in the eco-environment of the whole basin. The river's effective supply for the demand of natural ecological water, is able to sustain and improve the natural ecological balance of the basin, 
and is then beneficial to the stable development of the basin's economy and society, which is also a reflection of its positive externality. On the contrary, if the society seeking after the river's resource functions are indulged, to the extent that the red line for river ecosystem health is crossed and protection of ecological water is ignored, then the river channel's eco-environmental functions will be damaged, ecosystems will collapse, and ultimately hinder the realization of the river's resource functions, which are the reflections of its negative externality.

2) Neighborhood externality of ecological water rights. The property rights neighborhood means the region adjacent to the power \& function scope of diverse property rights. The Yellow River flows through 9 provinces from Qinghai to Shandong, and neighboring relations exist between provinces of the upper and the lower reaches. The water consumption by provinces of upper reaches will produce neighborhood externality consequences for provinces of the lower reaches. Moderate water use, waste water discharge that meets the standards and plantation and water source protection not only benefit water-use safety for the upper reaches but also safeguard ecological water quality for provinces of the lower reaches; on the contrary, excessive water use by provinces of upper reaches and over-discharge will generate negative neighborhood externality to the ecological water of provinces in the lower reaches. The cut-off crisis of the Yellow River from the 1970's to the 1990's serves as a typical example of ecological water rights violations of the lower reaches by the upper reaches.

3) Intergenerational externality of ecological water rights. The river-life-sustaining water rights are shown by the water-use rights the river claims from humans, which are in essence the rights to use water fairly advocated by descendants to predecessors [1]. For this reason, the protection of ecological water rights shows characteristics of intergenerational externality. Apposite ecological water constitutes the basic condition for sustaining the health of the river, benefiting the production and operation activities of contemporary people as well as the existence and development of future generations. In brief, sustainability of ecological water underpins that of human society.

\subsubsection{Weak Exclusiveness}

The property rights' exclusiveness refers to the income generated and consequences undertaken when the subject of property rights is authorized to prevent others from using the owned property and has it solely occupied and used. The stronger the property rights' exclusiveness and the subject's exclusiveness capacity are, the higher the property rights quality and performance efficiency will become.

Theoretically, The Yellow River's ecological water rights feature exclusiveness to a certain degree. In terms of the property rights object, according to stipulation of the Allocation Plan of the Yellow River's Available Water Supply issued in 1987, the Yellow River Conservancy Commission firstly guarantees at least 21 billion $\mathrm{m}^{3}$ of water in the river channel of the lower reaches for sediment transportation, and then determines the monthly water-allocation indicator of all 
provinces pursuant to the annually available water supply allocation indicators of normal inflow as well as the proportion of the current year's available water supply; that is, the Yellow River's initial allocation of water rights is implemented after reservation of ecological water. This stipulation clearly distinguishes the ecological water from the social water, specifies ecological water consumption volume, and draws the line between the ecological water rights and the social water rights, enabling the ecological water rights to be characterized for certain exclusiveness. In terms of the property rights subject, on the other hand, according to stipulations of the Water Law of our country, the water resources are owned by the state. Therefore, the ecological water rights are publicly-owned property rights, with the state as the property rights subject. What needs to be mentioned is that the publicly-owned property rights feature certain degrees of exclusiveness as well: "The exclusiveness, though not existing among elements within the publicly-owned property rights, does exist between the publicly-owned subject and the private subject. The publicly-owned property rights as a whole excludes any member from embezzling or splitting the publicly-owned property rights. The state, as the property rights subject, owns the property rights on behalf of the entire people, and exclusive relations exist between the entire people and entities \& individuals, namely preventing individuals from appropriating public property" [6]. It thus can be seen that the state, as the property rights subject, has the powers and responsibilities to exclude any entity or individual from using ecological water. Therefore, excessive water consumption and over-standard discharge conducted by private enterprises as well as the indulgence and acquiescence by local governments of different provinces constitute violations of national ecological water rights.

As a matter of fact, the exclusiveness of ecological water rights is not yet complete and mainly manifested as follows: the ecological water is a kind of flowing common resource, and features consumptive exclusiveness. The ecological effect generated by it features externality, which is non-exclusive. These resource characteristics determine the non-exclusive characteristic of ecological water rights. The state, the property rights subject, is actually an abstract concept, and the actual subject of implementation of the Yellow River's ecological water rights are government departments, including the Yellow River Conservancy Commission, local water administration department and environment protection department. In the course of practical operations, the powers and responsibilities of multiple ecological water rights subjects are not clearly defined, and exclusive measures are restricted: on the one hand, organs of the basin cannot prevent local protectionism of provinces along the Yellow River, and local governments at all levels often indulge and acquiesce in the excessive water use and over-standard discharge by enterprises located in their own provinces for the purpose of pursuing local performance; on the other hand, there is no exclusiveness between provinces of the upper reaches and those of the lower, and the common resource characteristic of ecological water results in fierce competition among provinces along the Yellow River in utilization. The upper reaches have the advantage of 
water use, while the lower reaches can hardly exclude the upper reaches' conduct of over-occupation of ecological water, and have no choice but to assume the negative ecological consequences caused by the upper reaches.

To sum up, the Yellow River's ecological water rights are merely endowed with the exclusiveness of the legal aspects, but the exclusive capacity of the ecological water rights subject are insufficient under the management system of multi-subject governance with unclear powers and responsibilities, as a result of which effective, exclusive protection measures against the conduct of violating ecological water rights cannot be implemented. Therefore, the ecological water rights do not possess practical exclusiveness.

\subsubsection{Incomplete Limitation}

The limitation of the property right means that the property right must be well defined, which includes two aspects: firstly, well definition among different property rights in order to benefit property right transactions and solve property right conflicts; secondly, any property right must have the definition of its own, that is, the quantity or scope of certain specific right shall be explicit enough, and so shall be the rights and interests of different sub-rights divided from the same property right. The limitation and the exclusiveness of the property right supplement each other. The property right's limitation is the sufficient condition of the exclusiveness. The more well the property right is defined, the higher the exclusiveness degree will be, and in case the setting of the property right lags, the definition will be ill. When the property right subject is protecting, disposal and utilizing the owned property right, failure in effectively executing the exclusion will probably incur conflicts. Therefore, clear defining of property right shall include both that between the ecological water rights \& the social water rights and that among different sub-rights in the right bundle of ecological water rights.

The property right defining of ecological water rights of the Yellow River is obviously incomplete. Stipulations about ecological water reservation volume in the "1987 Water Allocation Plan" only roughly define the quantity between the ecological water rights and the social water rights. As the systems relevant to water right (water right defining in particular) in our country are still not complete enough, the property right subject and its powers and responsibilities as well as the property right object are not specifically defined. Therefore, the definition of ecological water rights itself is incomplete, such as unclear division of powers and responsibilities of the Yellow River's ecological water rights by water administration departments and local governments under the multiple management system, unclear defining of enforcement conduct and performable subject of other ecological water rights apart from the ownership, and lack of quantity defining of physical form of property right objects like ecological water demand quantity and quality under different ecological objectives.

\subsubsection{Non-Transferability}

The transferability of the property rights, also named as tradability, refers to the 
transfer and assignment among different subjects. The transfer/trading of the property rights may help to realize resource flow and reconfiguration by relatively low costs. The exclusiveness and limitation of the property rights serve as preconditions of the tradability: on the one hand, the property rights subject may be authorized to have the property rights traded, in the event that the subject is one \& only and monopolistic; on the other hand, in case of equal-value trading, the trading object must be well defined and be accurately measurable. Besides, the tradability of the property rights, which is not equal to its trading, is the precondition of the property rights trading.

The ecological water rights do not possess transferability due to weak exclusiveness and incomplete limitations, nor can it be permitted for transfer in the real world. The Yellow River's ecological water rights employ publicly-owned property rights system arrangements, and the property rights, under the management systems of multi-subject governance by organs of the basin and local administrative institutions, does not feature uniqueness and monopoly. Furthermore, a complete market access of the ecological water, as a kind of non-exclusive public goods, may achieve momentary interests at the sacrifice of the eco-environment. Therefore, for the purpose of safeguarding ecological water use safety and guaranteeing that the Yellow River's ecological water will not be used for other purposes, the Ministry of Water Resources of the People's Republic of China pointed out in Some Opinions of the Ministry of Water Resources on the Transfer of Water Rights that the water rights allocated from the eco-environment can neither be transferred nor assigned to water users in industries restricted for development by the state [7] [8].

\subsubsection{Shallow Division-and-Peeling Degree}

The property rights are not only one single right but also a bundle of entitlements composed of a number of sub-rights like ownership, right to use, and income right, etc. Goods feature multiple attributes and functions, and the single property rights subject cannot be fully wielded in most cases, thus the resource allocation and utilization efficiencies can be reinforced by dividing and peeling off multiple sub-rights and then having them defined to different property rights subjects. The more detailed the property rights are divided and the more thorough spitted out, the more sufficiently the resource is utilized. In addition, the divisibility of the property rights differs from its realistic disintegration. Any property right features divisibility, but whether it is disintegrated realistically depends on property rights defining, enforcement ability and social economic conditions, and the extent (or limitation) of peeling is determined by comparison of costs and incomes for property rights division. Water rights division usually refers to division of rights of water resource use. Currently, in foreign countries like Chile and America, transfer right, mortgage right and borrowing right are further divided and split out of the water use rights. Transfer of water rights refers to compensated assignment among different subjects. The mortgage of water rights means obtaining a bank loan through mortgaging the water use 
rights. The borrowing of water rights means lending or depositing the water use rights and having it recovered when necessary.

Theoretically, as a right to use river resources, the ecological water also, just like other water rights, features divisibility, and may have the rights of transfer, mortgage and borrowing divided and split out as per specific usage modes. In reality, for the purpose of avoiding the adoption of the ecological water for economic use, the Water Law prescribes that the ecological water cannot be transferred, and hence the transfer right cannot be divided from the ecological water rights. Likewise, the ecological water rights shall not be used for commercial mortgage, so the mortgage right cannot be divided from the ecological water rights. Owing to the characteristics of water demand on the river ecosystem, such as large interannual variations of river inflow and strong seasonality of the river's ecological water demand, it is thus necessary to effectively adjust the supply of ecological water based on such characteristics, for example, depositing a part of the ecological water rights during the plentiful period of the river for prospective extraction in the dry season, or the purchase of other water rights to supplement ecological water, namely achieving more effective supply of ecological water through borrowing of water rights. However, current ecological water rights do not own the conditions for division of borrowing right. On the one hand, the water rights trading mechanism of our country develops slowly, with configuration of water rights trading institutions (such as "Water Rights Bank" and "Water Rights Exchange") lags behind, and the ecological water rights are not yet equipped with environmental conditions for depositing and borrowing; on the other hand, the ecological water rights are of multiple property rights subjects without uniqueness and monopoly, which goes against the market trading.

In brief, the ecological water rights possess the theoretical divisibility as well as the realistic demand for further division, but realistic disintegration of ecological water rights is not realized due to the incompleteness of a property rights defining system for ecological water rights, the water rights market trading mechanism and the water rights market construction.

\subsubsection{Poor Enforceability}

The enforceability of the property rights refers to all rights with which the property rights owned by its subject may be effectively enforced, implemented and protected. As to powers and functions of the property rights, the enforceability refers to what the property rights subject is authorized to do, not do and prevent others from doing within the scope of powers and functions. Realization of property rights income relies on the enforcement behavior by the property rights subject. The property rights behavior mainly includes protection behavior, exclusion behavior, internal management behavior and disposal behavior, etc. The property rights behavior is the enforcement of powers and functions, with assets as the basis and gaining benefits as the purpose. Whether the property rights can be effectively enforced is determined by two conditions: firstly, whether the 
property rights subject has the will of enforcing powers and functions of the property rights; secondly, whether the property rights subject has the capacity of enforcing powers and functions of the property rights.

At present, the enforceability of the Yellow River's ecological water rights are relatively poor, which is attributed to two reasons: one is that the management subject of the Yellow River's ecological water lacks the behavioral intention of implementing exclusive protection for ecological water. On the one hand, the ecological water is a public resource, and the ecological benefit generated by it belongs to public benefit that features strong externality, which is unable to directly produce economic interest and form encouragement of property rights-enforcement behavior to all administrative subjects; on the other hand, because of multi-subject ecological water management and unclear defining of powers and responsibilities, the consequence of ecological water rights violations have to be assumed by residents of the basin, while there exists no specific responsibility for investigation stipulations targeting the management subjects. Therefore, neither the Yellow River Conservancy Commission nor local water administration departments of provinces have the will of proactively enforcing the behavior of exclusive protection against violation of ecological water. The other is that the management subject of the Yellow River's ecological water does not have the eligible property rights-enforcement capacity. The Yellow River, the second largest river in our country, boasts a vast basin area, and the management of ecological water involves management of water resource in the whole basin, thus joint consultation and management between organs of the basin and local water administration departments is required so as to have the unified control of ecological water in the entire basin come true. Nevertheless, stipulations in the Water Law regarding basin management is not that detailed, and unclear legal status and mediocre authority of organs of the basin leads to a situation where the basin management is subject to the management of local administrative regions. Natures of agency of the Ministry of Water Resources and public institution have confined the authorities of organs of the basin, which hinders coordination or joint management between the Yellow River Conservancy Commission and local departments. The right of participating in local water affairs by the management of the organs of the basin is thus limited.

To sum up the above analysis, the Yellow River's ecological water rights feature property rights characteristics like strong externality, weak exclusivity, incomplete limitation, non-transferability, shallow division-and-peeling degree and poor enforceability. Therefore, the property rights quality of ecological water rights is extremely low.

\subsection{Systemic Root of the Weakening of the Ecological Water Rights Quality of the Yellow River's Lower Reaches}

It can be seen from the aforesaid content that the quality of ecological water rights is low due to influence from public resource characteristics like public in- 
terest and externality as well as stagnant construction of the relevant water rights systems, especially property rights defining system and water rights ranking \& allocation systems, etc.

\subsubsection{System of Water Rights Definition}

1) Unclear definition of ecological water rights object.

The ecological water rights object of the river refers to the water resource utilized and consumed by the river to maintain its eco-environment functions, namely the ecological water of the river. The vague definition of the Yellow River's ecological water rights object is mainly manifested by two aspects: lack of definite and strict definition for conception and connotation of ecological water, and calculating mode diversity of ecological water demand. On the one hand, ecological water is a multi-disciplinary comprehensive conception that crosses ecology, hydrology and resource \& environmental science. Scholars of different disciplines have different comprehensions on connotation of ecological water from profession perspectives of their own, and the adopted calculating methods for ecological water demands as well, as the results derived, thus differentiate them from each other. According to figures, there are more than 170 hydrological indexes and approximately 158 calculating methods relevant to the river's ecological water demand both at home and abroad, such as the 7Q10 Method, the Tennant Method, the Wetted Perimeter Method, the CASIMIR Method, the Most-arid Month Average Flow-rate Method, the Monthly Guaranteed Frequency Method and the Fish Habitat Method, etc. [3]. Lijuan Li, Hongxing Zheng et al. (2000) set average annual values of observed runoff volumes in the month of minimum river flow from the perspective of natural eco-environment balance [9]; Xiqin Wang, Changming Liu et al. (2003) aimed on the most prominent pollution problem of the Yellow River's water, and figured out the minimum eco-environment water demand of the river channel of the lower reaches of the Yellow River by employing the monthly (annual) assurance rate setting method, the result of which was 5.2 billion $\mathrm{m}^{3}$ [10]; SU Qing (2006) considered that the Yellow River's eco-environment water rights should be regulated in the form of flow, without consideration of water quantity required for dilution of excessive pollutants by the Yellow River, the ecological water rights requirement should be that the flow poured into the sea at Lijin Station shall be no less than $150 \mathrm{~m}^{3} / \mathrm{s}$ [1]. Varied calculating methods feature varied data requirements, theoretical bases, applicable scopes and advantages \& disadvantages, and thus it is relatively difficult to unify the calculating standards of ecological water demands.

On the other hand, the river ecosystem is a complicated hydrologic cyclic process. The confirmation of ecological water demand is indeed complicated, which features requirements on not only water quality \& quantity but also time \& spatial distribution. The ecological water demand confirmed by the "1987 Water Allocation Plan" is not distinct enough, which may preliminarily relieve the Yellow River's cut-off problem but scarcely meets multiple aspects of eco- 
logical water requirements in the long run. It is calculated that, without consideration of water quality changes, with $20 \%$ sedimentation permitted, a water rights of 21.22 billion $\mathrm{m}^{3}$ is required for $4000 \mathrm{~m}^{3} / \mathrm{s}$ bank-full discharge when water \& sediment regulation technology is adopted. In this case, the Yellow River's ecological water rights requirements may be met by the indexes of the "1987 Water Allocation Plan" of the State Council. However, the flow to maintain the balanced sediment transportation and basic eco-environment will turn to approximately 35.77 billion $\mathrm{m}^{3}$ when the bank-full discharge is $2600 \mathrm{~m}^{3} / \mathrm{s}$, overpassing the water rights allocation quota of the "1987 Water Allocation Plan" (Qing Su2006). It thus can be seen that the currently allocated ecological water rights will be unable to meet the actual ecological water demand along with the Yellow River's decrease of inflow. Moreover, with the consistent increase of waste water discharge, the river's self-cleaning capacity will gradually decline, and deterioration of water quality will aggravate scarcity of ecological water. Therefore, the confirmation of current ecological water demand of the Yellow River lacks elasticity.

2) Unclear definition of ecological water rights subject and its powers and responsibilities

Unlike other water rights, the subject of resource utilization for ecological water rights is not the same as that of property right. The subject of ecological water includes the river channel as well as the ecology inside and outside it, which is not equipped with the property rights enforcement ability. Therefore, other organizations or individuals that feature abilities of enforcement and property rights maintenance shall enforce the ecological water powers and responsibilities on its behalf. The attribute of public resource of the river's ecological water determines the fact that the subject of ecological water is a governmental department.

Our country's water resource management system, a combination of basin management and administrative region management, which nominally realizes the unified management of the Yellow River, adopts a decentralized management mode in the actual operation. The management system of multi-subject governance leads to the diversification of subjects of ecological water rights, and powers and responsibilities of all management subjects are not clearly defined. Furthermore, the powers of basin organs and local governments overlap and intersect with each other. As the management organ of the basin, the Yellow River Conservancy Commission indeed owns the function of administrative director of water but, due to limited conditions for water administration law enforcement, not compulsory law enforcement and punishment, may have difficulty restraining local protectionism. Regarding the occupation and pollution problem of ecological water, there is no direct specific responsibility subject, leading to the fact that all management subjects are short of behavioral encouragement for initiating advanced exclusive protection measures for ecological water rights and skirt responsibilities when a serious water ecology crisis emerges. Moreover, the ownership of ecological water is owned by the country, and provinces from the 
upper reaches to the lower are all subjects of using the rights of ecological water, with their powers and responsibilities unclearly defined.

\subsubsection{Water Rights Ranking System}

The water rights ranking system means regulating the water-drawing sequence of different water-use subjects according to certain principles. The economic development propels increasing scarcity of the river's water resource, and water-drawing conflicts thus inevitably come into being since different water rights subjects take the water in the mean time. Exclusiveness is indeed able to solve such rights conflicts among the interests, but the fact that the water rights feature non-exclusiveness signifies the situation that conflicts among water-drawing rights have to be solved through coordination as per water rights priority sequence instead of exclusiveness. Statements about ecological water rights sequence in current laws and regulations of our country, however, are very vague [11]. It is stipulated by Article 21 of the Water Law that development and utilization of water resources shall meet the domestic water use of urban and rural residents in the first place, and simultaneously the demands from agriculture, industry, eco-environment and shipping shall be considered as well. In arid and semi-arid lands, development and utilization of water shall have the water demands from the eco-environment fully considered. It is also stipulated by Article 26 that construction of water conservancy power stations shall protect the ecology and environment, and simultaneously the demands from flood prevention, water supply, irrigation, shipping, bamboo floating down and fisheries shall be considered as well. Taking the stringency of laws and flexible treatment of water-use conflict into account, the Water Law, apart from specifying the top rank of domestic water rights, does not make it clear for the water-drawing sequence of other types of water rights. Legislative terms like "simultaneously considered" and "fully considered" do reflect, to some extent, the recognition and stress on the status of ecological water by our laws, while obscure wording and expressions fail to provide any help for protection of ecological water safety in judicial practice. The ill-targeted stipulations still have the ecological water and scenic water rights included in the domain of "common property right", which cannot achieve the entire (whole-basin) benefit maximization [12]. In addition, the organizational structuring that is responsible for determining the current water rights sequence is not reasonable. According to the Regulations on Water-drawing Permit, the State Council authorizes the provincial governments to figure out water rights sequence, which, as local administrative organs, usually have the order of ecological water rights, which does not generate direct economic benefit, postposed in consideration of provincial economic development.

\subsubsection{Water Rights Allocation System}

The water rights allocation includes three types: administrative water allocation, market water allocation and coordinative allocation. In the primary stage of water rights allocation, our country adopts administrative water allocation, carry- 
ing out the initial allocation of water rights based on the reservation of ecological water. The "1987 Water Allocation Plan" reserves no less than 21 billion $\mathrm{m}^{3}$ sand-flushing water in the lower reaches as the ecological water of the Yellow River. However, there is no stipulation relevant to the re-allocation stage of ecological water rights, and the guidance mechanism of regulating ecological water supply is in great need. The region and season have a large influence on the ecological water demand of the river. For instance, the period from April to June of each year is for the spawning of fish, which requires relatively high levels of water quality \& quantity. The reserved volume of ecological water in the primary allocation of water rights is a normal value that takes multiple river functions into consideration, and is unable to meet the requirement of effectively allocating the ecological water as per ecological water demand characteristics of the river. To exert market force by a water rights market is the fundamental solution for further optimization of water resource allocation. Well-defined property rights and the existence of exclusiveness are the basis of market exertion, and market force will disappear when the market is not clearly defined. Without a well-defined property rights subject, the regulation of ecological water supply through the market in a flexible way according to the rivers ecosystem demands will be impossible.

\section{System Optimization for the Protection of Ecological Water Rights of the Yellow River}

The main reason for the vulnerability of the ecological water rights in the lower reaches of Yellow River lies in the stagnant construction of relevant water-rights systems. Combining with the forgoing analysis, this paper suggests necessary system optimization shall be done in the four aspects, namely improving the system of the ecological water rights defined, refining the water rights ranking system, utilizing the water rights market and upgrading the management system of ecological water rights.

\subsection{Improving the Defining System and Enhancing the Exclusiveness of the Ecological Water Rights}

\subsubsection{Clarifying the Object of the Ecological Water Rights}

To unify the cognition towards the property rights object of the ecological water rights serves the premise of clarifying and defining the ecological water rights. National water administration departments and organs of the basin can combine suggestions from multi-discipline scholars to unify the concept definition of the ecological water rights of rivers. On this basis, the departments and organs can lay down the ecological water demand under different targets of eco-environment. For example, according to the preservation and the recovery degrees of the river ecosystem, the ecological water demand can be classified into the lowest, the proper and the optimal demand. It shall be clear that the primary task of the ecological water rights is not to give the water demand or threshold of the river ecosystem with universal relevance, but to generally conclude the determining 
principles of water consumption and its threshold of the river-ecosystem, including principles of functional demanding, dividing periods, dividing channel segments, prioritizing main functions, maximizing efficiency, coordinating multi-functions and optimizing whole rivers (Jinren $\mathrm{Ni}$, Shubin Cui, Tianhong Li, et al. 2003) [13].

\subsubsection{Clarifying the Subject of Ecological Water Rights}

The water resources can only be used in high efficiency if the water rights are defined in the hands of subjects that are able to enforce the rights effectively. For the subject definition, domestic scholars, based on resource ownership and river \& country spokesmen, hold that the subject of the ecological water rights shall be defined within the water administration departments of the State Council [1] [7] [12]. Since the Water Law stipulates that all resources are owned by the state, the ownership of ecological water belongs to the state, which is enforced by the State Council. But as an "ultimate ownership", this right can only exert exclusiveness on the national level and is unable to restrain over-occupation of other water rights subjects of the country. Or it costs too much, restricting ecological water rights violation by the central government's supervision and punishment to be put into practice. Therefore, without well-divided responsibilities and well-defined rights, this ownership is still a virtual one which cannot exercise the protection of exclusiveness of the water right. This virtual national ownership is the systemic root of the vulnerability of ecological water rights.

This paper suggests, on the basis of the principle of state-owned ecological water, defining the ecological water rights, which are river-water management rights, to local governments of the basin, and "binding" the rights with other water rights of local governments. As the subject of the ecological water rights, local governments enjoy the use, the usufruct and the disposition rights of ecological water flowing through their provinces. An important function of property rights is defining the rights for property benefit or loss, as well as compensation issues. For the negative externality of the eco-environment, which the upper reaches exert on the lower ones, the local governments of the lower reaches with ecological water rights can, according to laws, claim compensation to realize the sustainability of ecological water of the whole basin. For example, to coordinate the water drawing among different states to guarantee the safety of ecological water, 46 states in US have got flow management rights of the river channels, among which, 11 states have stipulated that by laws and regulations.

\subsection{Refining the Water Rights Ranking System and Advancing the Rank of Ecological Water Rights}

In the Water Law, statements about the ranking of ecological water rights are very vague, which goes against solving the violation problem of ecological water rights in reality. In the future legislation, the ecological water rights ranking shall be cleared and enhanced. Many foreign countries, after experiencing the water eco-crisis due to the over-development of water resources, gradually stress the 
status of ecological water rights and specify that in acts of water resources. For example, South Africa prioritizes ecological water in the preferential position. The Water Law of South Africa states, "Basic living water and ecological water shall be satisfied first and water in other aspects like industry and agriculture can then be considered". The US 2002 Environmental Law states, "Besides the water consumption and the use of water body, the necessary ecological minimum-flow must be reserved inside the water channels" [14].

Domestic scholars point out suggestions for clarifying the ranks of ecological water rights: Bingyu Song and Jie Yang (2003) put forward, "The allocation of water resources shall transform from discounting ecological water to planning $\&$ guaranteeing socioeconomic water on the premise of ensuring the ecological water". That actually ranks the ecological water rights higher than the economic water [15]. Jilian Hu and Lei Chen (2013) hold that, during the process of original allocation of property rights of river-water resources, the ecological and scenic water rights shall be put for allocation only after the living water right, to guarantee the ecological water demand of species diversity, critical growth periods of plants and animals, natural reserves and rivers in extreme water scarcity [12]. Pingji Shan (2016) considers that our country shall adopt the water-rights priority rank in the following order: water for living, eco-environment, agriculture, industry, entertainment and others [11].

Referring to and learning from system structure and advice from scholars both at home and abroad, this paper suggests that the Water Law of our country shall, based on refining the categories of "three water rights", clarify and enhance the rank of ecological water rights. According to water demand, the ecological water rights can be divided into the basic and the optimal ecological water rights; among which, the basic ecological water rights are to preserve the lowest ecological water demand and the needed water quality for the river ecosystem to keep steady; while the optimal ecological water rights means the optimal ecological water demand and the needed water quality for the ecosystem to keep sustainable. Food security is the prerequisite for that of the state, thus the water rights of food crops must be guaranteed. The agricultural water rights can be divided into water rights of food crops and of other agricultural items. Based on that, the water rights can be divided into three classes: the first is living water right; the second includes water rights of food crops and basic ecological water rights; the third is other agricultural water rights, the optimal water rights and other water rights. The first class ranks higher than the second, while the second class ranks higher than the third. In the areas with water ecosystem seriously damaged, the basic ecological water rights in the second class ranks higher than that of food crops. The losses suffered by farmers due to crop reduction shall be compensated by local government.

\subsection{Strengthening the Effective Supply of Ecological Water by Utilizing the Water Rights Market}

If the public resources can be exclusive by certain system, the market can be uti- 
lized to adjust resource supply. The allocation of ecological water shall, based on the leading role of governments, fully employ the water rights market, and realize the effective supply by the re-allocation of water rights [16]. To remedy the ecological water shortage resulting from the over-issuing of water-drawing permits in the early years, the Australian government increases the supply of ecological water by repurchasing water rights. In 2004, the Australian government paid 500 million AUD for 500 million $\mathrm{m}^{3}$ water from the owner of the Murray-Darling basin water-rights. The government reserves the water at the Murray basin as ecological water, to solve the ecological water environment. Since the ecological water rights of property-rights subjects are clarified, the corresponding interest representatives (or spokesmen) come into being. They are able to enter into the water rights market on behalf of the river eco-system and increase the supply of ecological water by means of leasing, transferring, purchasing and receiving. The storing, borrowing and purchasing of ecological water can also be realized by a water rights bank and exchange. In addition, transaction and water diversion among other water rights, which endangers aquatic organisms in the river, shall be banned.

\subsection{Upgrading the Management System of Ecological Water Rights and Boosting the Labor Division and Collaboration among Water Management Organs}

It is the sole and practical choice for the current and the future management of water resources of the Yellow River to adopt the multi-subject water-resource management system which combines the unified basin control and local administrative management. The improvement of the present situation of the whole basin cannot go without the distribution and the coordination of all departments. The prerequisites for the orderly management of ecological water are to clarify the duties of each department or institution and to specify the practical coordination procedures among departments subject to laws. The national water administration departments and the Yellow River Conservancy Commission, in charge of the allocation, supervision and analysis of the ecological water in the basin, shall formulate unified mechanism systems of water quality supervision and evaluation to lay foundation for settling trans-provincial ecological-water disputes. Each provincial government and the local water management department along the Yellow River shall, according to the allocated ecological water volume, work together to formulate the plan of available water for the provincial economy, production and living, and ensure the ecological water volume needed by the river channel. By negotiation and compensation, the local government can solve the violation of ecological water rights in the upper \& lower reaches. The compensation funds are used to remedy the river ecosystem and to purchase water rights from the market to supply ecological water.

\section{Acknowledgements}

The author would like to thank Professor Xiujuan Wang (Shandong Agricultural 
University) for her comments and revisions on earlier versions of this paper.

\section{References}

[1] Su, Q. (2006) Study on Life Sustaining Water Right of the Yellow River. Journal of Sediment Research, 51, 1-9.

[2] Hu, A.G. and Wang, Y.H. (2002) How to Treat the Yellow River Cut-Off and the River Water Treatment-Investigation Report of the Yellow River Conservancy Commission. Management World, 18, 29-34.

[3] Wang, X.Q. and Zhang, Y. (2008) Situation Evaluation on River Channel Ecological Water Requirements of Seven Major Basins in China. Journal of Natural Resources, 23, 95-102.

[4] Zhao, M.H. and Zhang, X.H. (2011) Analysis of Eco-Environmental Water Demand in the Yellow River Channel. Yellow River, 33, 58-60.

[5] Luo, B.L. (2005) New Institutional Economics. Shanxi Economics Press, Taiyuan.

[6] Huang, S.A. (2004) Introduction to Property Right Economics. Economic Science Press, Beijing.

[7] Zheng, Z., Zheng, X.R. and Li, Y.F. (2008) Oases Ecological Water Rights Definition and Its Allocation. Journal of Arid Land Resource and Environment, 22, 71-75.

[8] Li, Y.L., Xie, Y.G. and Xie, Y.B. (2004) Definition and Allocation of Water Consumption Right of Eco-Environment. Journal of Hohai University (Natural Sciences), 32, 229-232.

[9] Li, L.J. and Zheng, H.X. (2000) Environmental and Ecological Water Consumption of River Systems in Haihe-Luanhe Basins. Acta Geographica Sinica, 55, 495-500.

[10] Wang, X.Q., Liu, C.M. and Zhang, Y. (2003) Study of the Basic Environmental Water Requirement of the Rivers in Huang-Huai-Hai Plain. Geographical Research, 22, 169-176.

[11] Shan, P.J. (2016) Legislative Construction of Priority Order Rules for Water Right in China. Tsinghua University Law Journal, 10, 142-159.

[12] Hu, J.L. and Chen, L. (2013) Research on the Operation and Management of River Resources Property Rights, the Yellow River for Example. China Agricultural Publishing House, Beijing.

[13] Ni, J.R., Cui, S.B., Li, T.H., et al. (2002) On Water Demand of River Ecosystem. Journal of Hydraulic Engineering, 47, 14-20.

[14] Shi, J. (2009) On Ecological Water Use Right of Rivers. China University of Political Science and Law, Beijing.

[15] Song, B.Y. and Yang, J. (2003) Discussion on Ecological Use of Water Research. Journal of Natural Resources, 18, 617-625.

[16] Hu, J.L. and Zhao, N. (2016) Study on the Market-Oriented Operation of Water Resource "Non-agricultural Transfer"-An Empirical Analysis Based on the Mountain Irrigation District in Liaocheng City, Shandong Province. Dongyue Tribune, 37, 24-35. 